\title{
Evaluation of different media for cell proliferation in mantle tissue culture of the green mussel, Perna viridis (Linnaeus, 1758)
}

\author{
C. P. SUJA ${ }^{1}$, V. SRINIVASA RAGHAVAN ${ }^{2}$, VIDYA JAYASANKAR ${ }^{2}$, I. DIVIPALA ${ }^{2}$, \\ M. BAREEN MOHAMED ${ }^{2}$, B. KONCIES MARY ${ }^{1}$ AND K. K. VIJAYAN ${ }^{3}$ \\ ${ }^{1}$ Tuticorin Research Centre of ICAR-Central Marine Fisheries Research Institute, South Beach Road \\ Tuticorin - 628 001, Tamil Nadu, India \\ ${ }^{2}$ Madras Research Centre of ICAR-Central Marine Fisheries Research Institute 75, Santhome High Road \\ RA Puram, Chennai - 600 028, Tamil Nadu, India \\ ${ }^{3}$ ICAR-Central Institute of Brackishwater Aquaculture, 75, Santhome High Road, RA Puram, Chennai - 600028 \\ Tamil Nadu, India \\ e-mail:cpsuja@gmail.com
}

\section{ABSTRACT}

\begin{abstract}
The aim of the present study was to establish a suitable culture system for tissue explants from the mantle of the green mussel, Perna viridis. The experiments were conducted using healthy, live green mussels in the size range of 75 to $110 \mathrm{~g}$ collected from Pulicat Lake, Tamil Nadu. Three different culture media namely M199, Leibovitz L-15 and sterile seawater were used to assess the most suitable medium for growth, proliferation and viability of mantle epithelial cells. The effect of the addition of two supplements viz., $10 \%$ foetal calf serum (FCS) and $0.1 \%$ yeast extract to the culture media was also evaluated. After carefully isolating the pallial layer from the mantle tissue, $1-2 \mathrm{~mm}^{2}$ size explants were successfully cultured in 12-well plates at $25^{\circ} \mathrm{C}$ for up to 14 days. Cultures were monitored under light and phase contrast objectives in an inverted microscope. Cell counts were made and cell size was measured for each treatment. Cells were observed to migrate from the periphery of the explant within $24 \mathrm{~h}$ after initiation of cultures. The liberated cells were mostly round and were either granulocytes or hyalinocytes. Fibroblast-like cells were also observed. Our results showed that proliferation of epithelial cells from mantle tissue was maximum in seawater medium $\left(7.4 \times 10^{4}\right.$ cells ml $\left.{ }^{-1}\right)$, followed by L-15 medium $\left(2.55 \times 10^{4}\right.$ cells ml$\left.^{-1}\right)$. Average cell size in seawater medium was $10.72 \mu \mathrm{m}$ and that in L-15 and M199 media was 8.56 and $6.39 \mu \mathrm{m}$, respectively. Adherent cells were also more prominent and higher in number in seawater medium. Supplementation of culture media with $10 \%$ FCS and $0.1 \%$ yeast extract improved both cell proliferation and cell size in all the three culture media. Four concentrations of $0.1 \%$ yeast extract (@ $50 \mu 1,75 \mu 1,100 \mu 1,150 \mu 1 \mathrm{ml}^{-1}$ medium) were tested in the present study and best results were obtained with $100 \mu \mathrm{ml}^{-1}$, with respect to both cell counts and size.
\end{abstract}

Keywords: Cell culture, Green mussel, Mantle epithelium, Perna viridis

The mantle tissue of molluscs is a thin, sheet-like membranous organ responsible for the secretion of an organic matrix by specialised cells of the outer mantle epithelium. Nacre is formed by the mantle epithelial cells as a mixture of calcium carbonate and proteins like conchiolin (Phuc et al., 2011). The shells of molluscs are a typical product of biomineralisation. It is well known that the shell's mantle, especially the outer epithelium plays a very important role in molluscan pearl and shell formation (Awaji and Machii, 2011; Xiang et al., 2014). Reports suggest that periostracum secreted by the mantle's epithelium initiates biomineralisation followed by the formation of the prismatic and nacreous shell layers in combination with the matrix protein (Wilbur and Saleuddin, 1983; Checa, 2000).

In vivo methods of pearl culture involve the implantation of a fragment of the epithelial layer from the mantle tissue prepared from a donor into the gonad of the recipient together with a small inorganic bead. The outer epithelial cells of the mantle fragment then form a follicle surrounding the bead, termed the pearl sac (Machii, 1968). The difficulties encountered with the current in vivo culture methods, such as uncertainty of survival of the recipient oyster in the natural environment, difficulties in manipulation of colour and quality of the cultured pearls and prohibitive cost of production make it necessary to develop methods for production of pearls by in vitro tissue/cell culture techniques. Besides, in vitro culture methods make it easier to study the mechanisms of pearl sac and pearl formation at cellular and molecular levels because culture conditions can be experimentally controlled and observations on changes in cultured mantle tissue can be made successively. The need for a novel model culture system to carry out these basic studies and the potential value of this technology for pearl culture industries have now made mantle tissue culture one of the leading areas in 
molluscan research worldwide. The primary culture of outer epithelial cells of the mantle tissue gives an insight to the pearl formation process. The primary cultures of mantle cells from various molluscs such as abalone (Suja and Dharmaraj, 2005; Suja et al., 2007), clam (Koyama and Aizawa, 2000; Dessai, 2012), mussel (Cornet, 2006; Quinn et al., 2009), scallops (Endoh and Hasegawa, 2006) and oysters (Awaji, 1997; Gong et al., 2008) have been obtained.

The appropriate culture conditions for mantle epithelial cells differ among varieties of molluscs. The success of a primary cell culture is significantly dependent on the culture medium and because different cell types have different growth requirements, it is necessary to formulate the most appropriate medium for a particular cell type. Formulation of a suitable medium for marine invertebrate cell culture, poses a big challenge, as most commercial media have been developed for use in mammalian cell culture and need to be modified with respect to osmolality, $\mathrm{pH}$ and nutritional components to simulate the marine environment. Therefore, the present work was envisaged to establish a suitable culture system for tissue explants from the mantle of the green mussel, Perna viridis (Linnaeus, 1758).

Three different culture media namely M199, Leibovitz L-15 (Sigma-Aldrich) and sterilised natural seawater were used to assess the most suitable medium for growth, proliferation and viability of mantle epithelial cells. Two supplements namely $10 \%(\mathrm{v} / \mathrm{v})$ foetal calf serum (FCS, Gibco laboratories) and $0.1 \%$ yeast extract (Sigma-Aldrich) @ $50,75,100$ or $150 \mu \mathrm{ml}^{-1}$ were added to the culture media to study their effect on the proliferation of mantle epithelial cells. All media and solutions were filter sterilised using $0.22 \mu \mathrm{m}$ filters of $47 \mathrm{~mm}$ dia. The $\mathrm{pH}$ and osmolality of the media were tested and adjusted to 7.4 and $\sim 1000 \mathrm{mOsm} \mathrm{kg}^{-1}$, respectively. Kanamycin antibiotic solution (50 mg $\mathrm{ml}^{-1}$, Sigma-Aldrich) was added at a concentration of $0.1 \%$ to the media before setting up the cultures. Glasswares were sterilised by autoclaving.

Healthy, live green mussels in the size range of 75 to 110 g were collected from Pulicat Lake, Tamil Nadu, transported to the laboratory and maintained in circular high-density polyethylene (HDPE) tanks containing filtered, UV-treated seawater. The tanks were well aerated and the animals were fed regularly with live algal feed. The animals selected for the experiment were kept overnight in seawater containing antibiotics penicillin-streptomycin (penicillin 10,000 units $\mathrm{ml}^{-1}$, streptomycin 10,000 $\mu \mathrm{g} \mathrm{ml}^{-1}$; Gibco laboratories) and fungicide amphotericin $\left(250 \mu \mathrm{g} \mathrm{ml}^{-1}\right.$; Sigma-Aldrich) solutions at a concentration of $100 \mu \mathrm{g} \mathrm{ml}^{-1}$ of seawater. Prior to the experiment, animals were thoroughly cleaned to remove the dirt/debris and byssus threads and surface of the animals was wiped with $75 \%$ alcohol. The valves of the green mussels were cut open with a dissection knife to expose the mantle tissue, gills and other visceral organs. The gills and viscera were removed and the mantle tissue was dissected out using a small scalpel and put in a glass bowl containing sterile seawater. The mantle was then flattened using a flattening forceps. Using a scalpel and forceps, the outer and inner layers of mantle were removed and the middle pallial portion of the mantle was taken and put in a sterile glass bowl containing seawater. The process was repeated for other mantle tissues. The mantle strips were treated in $35 \%$ alcohol for $30 \mathrm{sec}$, washed in sterile seawater, followed by two 10 min treatments in antibiotic solutions of penicillin and streptomycin $\left(100 \mu \mathrm{l} 10 \mathrm{ml}^{-1}\right)$ and amphotericin B $\left(100 \mu 110 \mathrm{ml}^{-1}\right)$. The antibiotic treated mantle tissues were then washed in sterile seawater several times and transferred to a small petri plate containing seawater. Each mantle tissue strip was placed over a clean, sterile, glass block and cut into small pieces of approximately $1-2 \mathrm{~mm}^{2}$ each using a BP blade. All the cut pieces were put in a small petri plate containing sterile seawater. Using a small hooked tissue holding forceps, two small pieces of $1-2 \mathrm{~mm}^{2}$ mantle tissue were placed into each well of a 12-well plate (Eppendorf) and kept undisturbed for 10 to 15 min for the tissues to dry and adhere to the bottom of the wells. Two ml of media with different combinations of supplements were added to the cell culture wells. The plates were then sealed with parafilm and incubated at $25^{\circ} \mathrm{C}$. All culture procedures were carried out under sterile conditions in a laminar airflow chamber. Plates were observed under an inverted microscope (Nikon). After 14 days of culture, cell size was measured for each treatment and cell counts were also made. Cells were harvested by centrifugation of cultures and a drop of the diluted cell pellet was loaded on to a haemocytometer for counting of cells. Viability of cells in culture was assessed using the trypan blue $(2 \%)$ dye exclusion assay.

The present study focused on the development of a suitable culture system for primary culture of tissue explants from the mantle of the green mussel, $P$. viridis. The progress of the explant cultures was monitored under an inverted microscope. The cells started migrating and emanating from the explants within $24 \mathrm{~h}$ post-incubation and formed aggregates. The liberated cells were mostly round and found to be either granulocytes or hyalinocytes, with granulocytes dominating the culture as reported by Li et al. (1966), Suja and Dharmaraj (2005) and Dessai (2012). Cell liberation was seen from the periphery of the explant. The appearance of fibrocytes and fibroblast-like cells was noticed after $24 \mathrm{~h}$ of incubation of cell cultures. The fibroblast-like cells were found to have different sizes ranging from small to large spindle shaped cells. Suja et al. (2005) reported the appearance of fibroblast-like cells on day 2 post-incubation in in vitro mantle tissue culture of abalone Haliotis varia and Dessai (2012) reported the appearance of spindle shaped cells on day 2 in Paphia malabarica. Daugavet and Blinova 
(2015) also reported the presence of fibroblast-like cells in the early stages of mantle cell culture in the blue mussel, Mytilus edulis. Cell density was found to be good when the plates were incubated at $25^{\circ} \mathrm{C}$. Suja et al. (2005) and Dessai (2012) found that the cell density was higher at $28^{\circ} \mathrm{C}$ and $20-25^{\circ} \mathrm{C}$, respectively. This suggests that incubation temperature could be one of the determining factors in the growth and proliferation of mantle epithelial cells. Contamination was also observed occasionally in the cultures with the major cause of contamination being bacteria and filamentous fungi (Table 1). Contamination was found to be around 32\% during the course of this study. Bacterial and fungal contaminations remain a serious problem in primary cell culture, especially for tissues that are directly exposed to seawater such as the gills and the mantle (Rinkevich, 1999; Van der Merwe et al., 2010).

Table 1. Prevalence of contamination in mantle tissue cultures

\begin{tabular}{ll}
\hline Type of contamination & Incidence \\
\hline Bacteria & 4 \\
Fungi & 2 \\
Total contaminated cultures & $6 / 19$ \\
\hline
\end{tabular}

Among the three culture media evaluated for the growth and proliferation of mantle epithelial cells, Leibovitz's L15 medium was better than M199 medium with respect to cell proliferation and cell size (Fig. 1, 3). Suja et al. (2007) reported that L15 medium gave better cell yield and M199 medium promoted better cell adherence in the in vitro mantle tissue culture of abalone $H$. varia. Dessai (2012) reported that
L15 medium in $2 \mathrm{x}$ concentration was found to be suitable for the primary cultures of mantle cells of $P$. malabarica thereby promoting migration and viability of cells. In the present study, addition of supplements (10\% FCS and $0.1 \%$ yeast extract) increased cell size and number (Fig. 2, 4). Among the four concentrations of $0.1 \%$ yeast extract tested, namely $50 \mu \mathrm{l}, 75 \mu \mathrm{l}, 100 \mu \mathrm{l}, 150 \mu \mathrm{l} \mathrm{ml}^{-1}$ medium, it was noted that $100 \mu \mathrm{l}$ per $\mathrm{ml}$ of medium gave better results with regard to cell proliferation and cell size in both L15 and seawater media (Table 2).

The present study has also found that sterile seawater medium gave the best results in terms of better growth, proliferation and cell size when compared to L15 and M199 media. The formation of adherent cells was also found to be better in sterile seawater medium (Fig. 5, 6). Van der Merwe et al. (2010) have reported the use of artificial seawater as a feasible alternative to Leibovitz based media for maintenance of abalone larval cell cultures. Sterilised, filtered natural seawater, supplemented with antibiotics, is also frequently used for sponge cell cultures (Rosa et al., 2001; Cao et al., 2007). The effect of different treatments on the proliferation of mantle cells of $P$. viridis is shown in Table 3 .

The cell cultures were also evaluated for the viability of cells using trypan blue (2\%) dye exclusion test after 14 days of incubation and it was found that more than $85 \%$ of the cells were found to be live with increase in the size of the cell.

The successful short term culture of mantle epithelial cells from $P$. viridis reported here reveals the prospects of

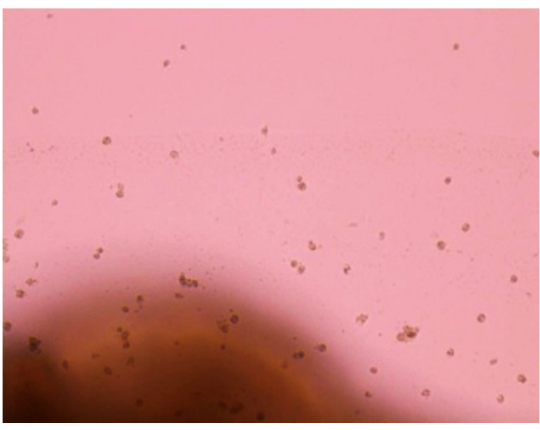

Fig. 1. Migration of cells from the periphery of the explant in L15 medium

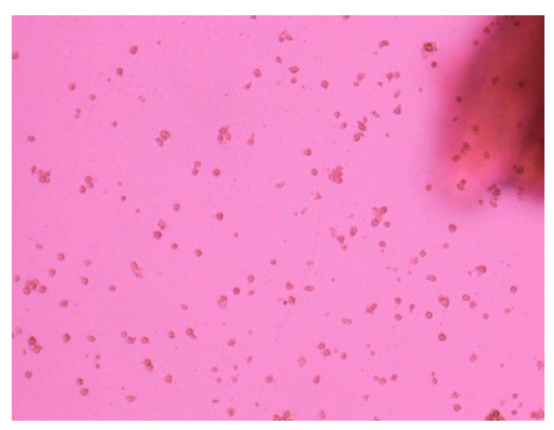

ig. 2. Proliferation of cells in L15 mediun with supplements

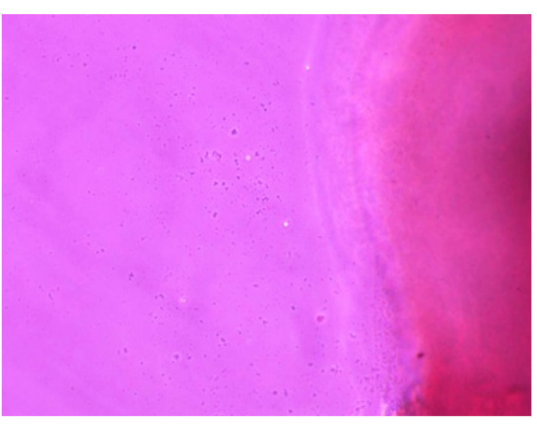

Fig. 3. Migration of cells from the periphery of the explant in M199 medium

Table 2. Cell number and cell size $(\operatorname{mean} \pm \mathrm{SD})$ in mantle explants from green mussel, Perna viridis cultured in media supplemented with $10 \%$ FCS and different concentrations of yeast extract (YE)

\begin{tabular}{|c|c|c|c|c|c|c|c|c|}
\hline \multirow{2}{*}{ Media } & \multicolumn{2}{|c|}{ YE $50 \mu \mathrm{l}$} & \multicolumn{2}{|c|}{ YE $75 \mu 1$} & \multicolumn{2}{|c|}{ YE $100 \mu 1$} & \multicolumn{2}{|c|}{ YE150 $\mu 1$} \\
\hline & Cell size* & Cell no.** & Cell size & Cell no. & Cell size & Cell no. & Cell size & Cell no. \\
\hline L15 & $8.76 \pm 1.17$ & $1.7 \pm 0.30$ & $8.23 \pm 1.25$ & $1.8 \pm 0.40$ & $13.31 \pm 0.16$ & $3.24 \pm 1.93$ & $10.46 \pm 1.15$ & $1.32 \pm 0.38$ \\
\hline M199 & $6.45 \pm 2.22$ & $2.02 \pm 0.86$ & $7.03 \pm 0.96$ & $2.28 \pm 0.27$ & $7.67 \pm 0.74$ & $2.57 \pm 2.79$ & $6.93 \pm 1.02$ & $2.45 \pm 0.65$ \\
\hline Sea water & $9.21 \pm 0.98$ & $9.4 \pm 1.10$ & $9.3 \pm 0.73$ & $9.4 \pm 1.96$ & $11.41 \pm 0.85$ & $11.5 \pm 0.70$ & $8.99 \pm 1.64$ & $7.8 \pm 2.40$ \\
\hline
\end{tabular}

${ }^{*} \mu \mathrm{m} ;{ }^{* *} 1 \times 10^{4} \mathrm{ml}^{-1}$ 


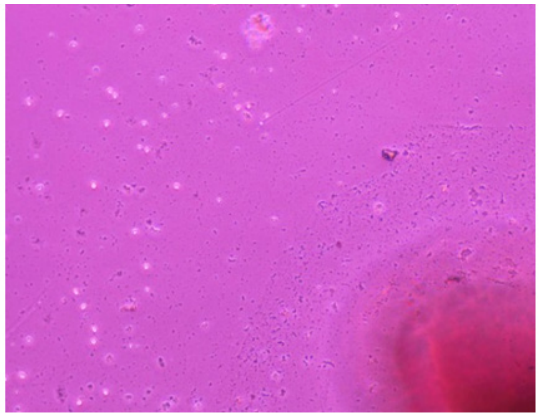

Fig. 4. Proliferation of cells in M199 medium with supplements

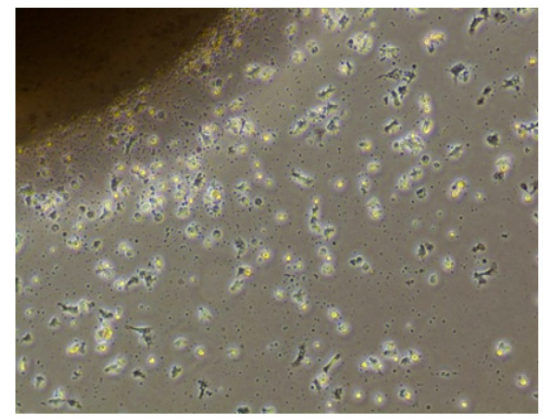

Fig. 5. Migration of cells from the periphery of the explant in seawater medium

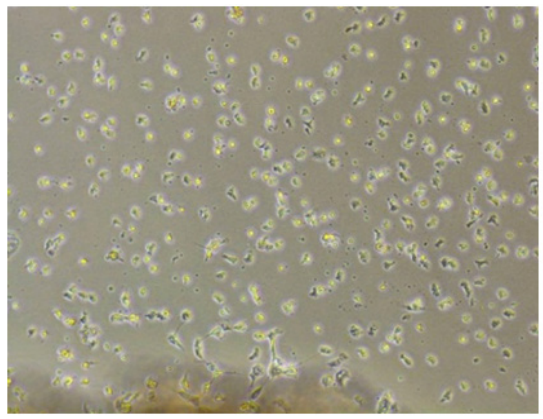

Fig. 6. Good proliferation of cells in sterile seawater medium with supplements
Table 3. Comparison of different media with regard to cell proliferation and cell size (mean $\pm \mathrm{SD})$ in mantle explant culture of green mussel, Perna viridis

\begin{tabular}{lll}
\hline Medium & Cell no. $\left(1 \times 10^{4} \mathrm{ml}^{-1}\right)$ & Cell size $(\mu \mathrm{m})$ \\
\hline L15 & $2.55 \pm 1.04$ & $8.56 \pm 0.54$ \\
L15 with supplements & $3.24 \pm 1.93$ & $13.31 \pm 0.16$ \\
M199 & $2.38 \pm 0.87$ & $6.39 \pm 1.22$ \\
M199 with supplements & $2.57 \pm 2.79$ & $7.67 \pm 0.74$ \\
Sterile seawater & $7.4 \pm 1.4$ & $10.72 \pm 0.46$ \\
Sterile seawater with & $11.5 \pm 0.7$ & $11.41 \pm 0.85$ \\
supplements* & &
\end{tabular}

${ }^{*} 10 \% \mathrm{FCS} ; 100 \mu 1 \mathrm{ml}^{-1}$ of $0.1 \%$ yeast extract

using sterile seawater with supplements as an alternative medium for mantle tissue culture, in place of expensive commercial media such as L-15.

\section{Acknowledgements}

The authors are thankful to the Director, ICAR-CMFRI, Kochi for his constant encouragement and support. The authors also wish to thank the Scientists-in-Charge, Tuticorin RC of CMFRI, and Madras RC of CMFRI, for facilitating this study.

\section{References}

Awaji, M. 1997. Primary culture techniques for the outer epithelial cells of pearl oyster mantle. In: Maramorosch, K. and Mitsuhashi, J. (Eds.). Invertebrate cell culture, Science Publishers, New Hampshire, p. 239-244.

Awaji, M. and Machii, A. 2011. Fundamental studies on in vivo and in vitro pearl formation - Contribution of outer epithelial cells of pearl oyster mantle and pearl sacs. Aqua-BioScience Monogr., 4(1): 1-39.

Cao, X., Fu, W., Yu, X. and Zhang, W. 2007. Dynamics of spicule production in the marine sponge Hymeniacidon perlevis during in vitro cell culture and seasonal development in the field. Cell Tissue Res., 329: 595-608.

Checa, A. 2000. A new model for periostracum and shell formation in Unionidae (Bivalvia, Mollusca). Tissue Cell, 32: 405-416.
Cornet, M. 2006. Primary mantle tissue culture from the bivalve mollusc Mytilus galloprovincialis: investigations on the growth promoting activity of the serum used for medium supplementation. J. Biotechnol., 123(1): 78-84.

Daugavet, M. A. and Blinova, M. I. 2015. Culture of mussel (Mytilus edulis L.) mantle cells. Cell Tissue Biol., 9(3): 233-243.

Dessai, S. N. 2012. Primary culture of mantle cells of bivalve mollusc, Paphia malabarica. In Vitro Cell. Dev. Biol. Anim., 48: 473-477.

Endoh, M. and Hasegawa, Y. 2006. Culture of mantle epithelial cells expressing shell matrix proteins from scallop Patinopecten yessoensis. Fish. Sci., 72: 1277-1285.

Gong, N., Ma, Z., Li, Q., Li, Q., Yan, Z., Xie, L. and Zhang, R. 2008. Characterisation of calcium deposition and shell matrix protein secretion in primary mantle tissue culture from the marine pearl oyster Pinctada fucata. Mar. Biotechnol.,10(4): 457- 465 .

Koyama, S. and Aizawa, M. 2000. Tissue culture of the deep sea bivalve Calyptogena soyoae. Extremophiles, 4: 385-389.

Li, M. F., Stewart, J. E. and Drinnan, R. E. 1966. In vitro cultivation of cells of the oyster, Crassostrea virginica. J. Fish. Res. Board Can., 23: 585 pp.

Machii, A. 1968. Histological studies on the pearl-sac formation. Bull. Natl. Pearl Res. Lab., 13: 1489-1539.

Phuc, P. V., Viet, P. Q., Hoang, N. M., Tam, N. T. and Ngoc, P. K. 2011. Research on in vitro culture and inducing nacre crystal formation of freshwater pearl mussel mantle epithelial cell Sinohyriopsis cumingii. Int. J. Fish. Aquac., 3(6): 105-113.

Quinn, B., Costello, M. J., Dorange, G., James, G. W. and Mothersill, C. 2009. Development of an in vitro culture method for cells and tissues from the zebra mussel (Dreissenia polymorpha). Cytotechnology, 59: 121-134.

Rinkevich, B. 1999. Cell cultures from marine invertebrates: obstacles, new approaches and recent improvements. J. Biotechnol., 70: 133-153.

Rosa, S., Caro, S., Tommonaro, G., Slantchev, K., Stefanov, K. and Popov, S. 2001. Development in a primary cell culture of the 
marine sponge Ircinia muscarum and analysis of the polar compounds. Mar. Biotechnol., 3: 281-286.

Suja, C. P. and Dharmaraj, S. 2005. In-vitro culture of mantle tissue of the abalone, Haliotis varia (Linnaeus). Tissue Cell, 37(1): 1-10.

Suja, C. P., Sukumaran, N. and Dharmaraj, S. 2007. Effect of culture media and tissue extracts in the mantle explant culture of abalone, Haliotis varia (Linnaeus). Aquaculture, 27: 516-522.

Van der Merwe, M., Auzoux-Bordenave, S., Niesler, C. and RoodtWilding, R. 2010. Investigating the establishment of primary cell culture from different abalone (Haliotis midae) tissues. Cytotechnology, 62: 265-277.

Wilbur, K. M. and Saleuddin, A. S. M. 1983. Shell formation. In: Saleuddin, A. S. M. and Wilbur, K. M. (Eds.), The mollusca. Academics, New York, p. 235-287.

Xiang, L., Kong, W., Su, J., Liang, J., Zhang, G., Xie, L. and Zhang, R. 2014. Amorphous calcium carbonate precipitation by cellular biomineralisation in mantle cell cultures of Pinctada fucata. PLoS ONE, 9(11): e113150.

Date of Receipt $\quad$ : 12.08 .2016

Date of Acceptance ： 07.02.2017 